\title{
多目的設計探查による設計空間の可視化と 知識発見
}

\section{下山 幸治 ${ }^{*} \cdot$ 杉村 和之 $^{* 2} \cdot$ 鄭 信圭 $* 1 \cdot$ 大林 茂 $* 1$}

\section{1. 緒言}

計算科学におけるシミュレーション精度の向上やコ ンピュータ性能の著しい発達に伴い, Computer Aided Engineering (CAE) を用いた設計技術への関心が高 まっている. CAEとは, 構造力学や流体力学などのシ ミュレーションにより, 設計対象の解析・評価を行う ことである。例えば，航空機の設計者が機体の形を決 めると，所定の飛行条件でどのような性能を持つかを 数值流体力学 (Computational Fluid Dynamics : CFD) により評価し，設計者にフィードバックすることがで きる。現在ではCFDの専門家が一人いれば，パソコ ンでも 1 日で格子生成から計算・計算結果の可視化ま で可能である。コンピュータ上で仮想的に試作を行 い，設計の検討を行うことができるので，コスト低減 と設計サイクルの短縮化が可能となる。これに対し， 一連の設計作業をCAEではなく風洞試験だけで行うと なれば, チームで数ヶ月単位の期間にわたって，模型 の設計製作から風洞試験・データ整理に取り組むこと になる。

1つ 1 つの設計対象の評価が簡単にできるようにな ると，あらかじめバリエーションを考え，それらを比 較しながら評価したくなる。そこで，コンピュータの 性能が上がると, パラメトリックスタディが行われる ようになってきた。さらにパラメトリックスタディが 容易になると，バリエーションを増やし，“最適な”組 み合わせを見つけたくなる。この作業を，設計者の経 験や勘に頼ることなく，コンピュータの力で自動的に 行う“最適化”に興味が高まっている。航空機の設計で は，機体形状を表現するパラメータを設計変数とし， 空力性能の向上を目的関数とした最適化を行う. 概念

$\dagger$ Multi-Objective Design Exploration for Design Space Visualization and Knowledge Discovery

Koji SHIMOYAMA, Kazuyuki SUGIMURA, Shinkyu JEONG, and Shigeru OBAYASHI

*1 東北大学流体科学研究所 Institute of Fluid Science, Tohoku University

*2 (株) 日立製作所 機械研究所

Mechanical Engineering Research Laboratory, Hitachi, Ltd.
設計の段階で最適化を含めた数值シミュレーションを 行うことで, 風洞試験による解析回数を必要最小限に 抑えることができる。例に挙げた航空機の設計に限ら ず, さまざまな工学設計の分野で, $\mathrm{CAE}$ と最適設計に 興味が集まっている.

現実世界で見られる設計問題では，考慮すべき目的 関数は唯一ではなく, 複数存在するのが通常である. 前述した航空機の最適化に抢いて目的関数となる空力 性能を例にとると, 揚力の最大化 ·抗力の最小化と いった様々な設計目標が存在する。また，設計目標は 空力のみならず，構造・推進・制御といった多分野に 渡ることもある。つまり，より実用的な設計を実行す るためには, 複数の目的関数を同時に考慮した“多目 的最適化”を行う必要がある。一般的な多目的最適化 問題では，一方を改良すると他方が改悪されるように 相反する設計目標が含まれることが多く, 各目標に対 する設計の妥協案を考える必要がある。理論的には, 多目的最適化問題の最適解は唯一に定まらず, 図 1 中 の黒丸で示される“Pareto最適解”と呼ばれる解の集合 として存在する. Pareto最適解とはすべての目的関数 について他のどの解よりも劣らない解を指し, その集 合は多目的最適化問題を支配する目的関数間の相反関 係(トレードオフ)を示唆するものである.

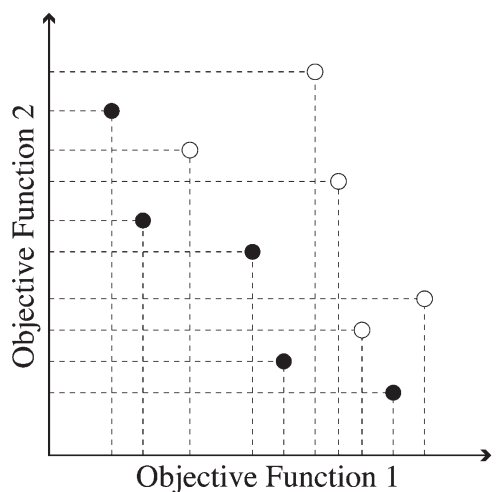

図 1 Pareto最適解集合 ( 2 目的関数最小化問題の場合) 
最適化を行うための手法は大きく 2 種類に分けら れ，1つは勾配法 (Gradient-Based Method : GM) [1]を代表とする 1 点探索手法, もう1つは遺伝的ア ルゴリズム (Genetic Algorithm：GA) [2,3]や粒子群最 適化 (Particle Swarm Optimization：PSO) [4] を代表 とする多点探索手法である。1 点探索手法は, 目的関 数の勾配情報に基づきながら，1つの解を逐次的に改 善していくものである。この特徴から，1点探索手法 は単一の最適解を持つ単目的最適化問題にしか対応で きず，多目的最適化問題を解く場合には各目的関数の 重み係数和をとって単目的最適化問題に帰着させる必 要がある。この場合，1回の最適化計算から得られる 解は, 重み係数の組み合わせに対応したPareto最適解 集合中の 1 点である. Pareto最適解集合の全体的な分 布を見出すためには，重み係数を変えながら最適化計 算を多数回試行する必要が出てくる. 目的関数の数が 増えるほど重み係数の組み合わせのバリエーションも 増えるため, 必要となる最適化計算回数も増える。ま た, Pareto最適解集合中に非凸部や不連続部が含まれ る場合には，いくら重み係数を変えても集合全体を見 出すことは理論上不可能となる。こういった 1 点探索 手法特有の問題に対して, Normal Boundary Intersection(NBI) Method[5]や希求水準法 (Aspiration Level Method) [6]といった解決方法も考案されている.

多点探索手法は進化的計算法 (Evolutionary Computation) とも呼ばれ, 設計空間全体に分布する複数 の解を用意し, それらの目的関数值から各解の相対的 な優劣順位 (ランク)を付け, ランクの高い解が存在す る領域に向けて解集団を作り替えていくものである. 複数の解を同時に探索することから，目的関数の評価 回数が解の個数分増えるというという久点はあるもの の, 多目的最適化問題では複数の目的関数を重み係数 和としてではなく個別のものとして扱うことができ る。これにより, 非凸性や不連続性に関係なく, Pareto最適解集合を 1 回の最適化計算で求めることが できる。

以上の説明から, 概念上は 1 点探索手法に比べて多 点探索手法の方が効率良く多目的最適化問題を解ける と言える。しかし実際には, 目的関数の数が膨大にな ると多点探索手法をもってしてもうまく解けなくな り, むしろ効率を犠牲にしてでも1点探索手法を繰り 返し用いた方が良好なPareto最適解集合を獲得できる 場合も報告されている $[7]$. また，このような問題に 対応すべく，多点探索手法について特別な改良策もい くつか提案されている(これらは文献 $[8] に$ 詳しくまと められている)。すなわち, 多点探索手法を多目的最 適化問題で効果的に活用するためには, 問題に応じて
適宜手法に改良を施す必要性が出てくるかもしれない ことに注意されたい。

単なる “最適化”では, 最適解を提示したところで作 業が終了するように思える。しかし, 設計作業として は，ただ 1 つの解を提示しただけでは役に立たない。 設計の各段階において, 各分野との擦り合わせで様々 なトレードオフが発生するため, 設計空間の中で多様 な設計候補を常に用意しておかなければならない。多 目的最適化から得られるPareto最適解集合はまさにそ の“多様な設計候補”に相当する。よって, Pareto最適 解集合が意味するトレードオフといった多目的設計空 間の構造的特徴を俯瞰的に可視化できれば，設計者は 設計候補を容易に選択できるようになる。これは従来 の設計方法にない利点であるため, 近年様々な分野で 多目的最適化の応用が試みられている (国際会議で報 告された最近の事例は文献[9]を参照されたい).

ところで, 目的関数が 2 つや 3 つならば, 図 1 のよ うにPareto最適解集合を目的関数空間上で単純にプ ロットすれば, 目的関数間のトレードオフの様子が見 て取れる。しかし，目的関数が 4 つ以上に増えると， このような単純プロットでトレードオフの様子を可視 化できない. 2 次元の目的関数平面に射影したり, 既 存の設計と比較したりすることで, ある程度解を吟味 して好ましい解を選ぶこともできるが，これでは Pareto最適解集合中の限られたほんの数個の解を調べ るに留まってしまう。このように高次元の設計空間に 隠されたトレードオフの様子を探るためには, “デー タマイニング”[10]の適用が有効であると考えられ る。データマイニングは情報科学分野(パターン認 識, 人工知能など) を起源とする技術であり, 複雑な データに潜在する特徴を人間にとって理解しやすい情 報形体 (数值, 画像, 文章など) に置き換えるものであ る、筆者らは，データマイニングの新たな用途とし て, 多目的設計空間を支配する構造的特徵を俯瞰的に 可視化し，新たな設計知識の発見に繋げることを目指 している。

設計問題に対するこのようなアプローチは, 最適化 を利用しつつ最終的に得ようとしている情報は設計空 間の構造であるという点で, 最適化技術に新しい切り 口を与えるものである. 従来, このように可視化まで を含んだ設計知識の抽出・提示に対して, 統一的な呼 称はなかった。そこで筆者らの研究グループでは, “最適化”と区別するために，このアプローチを“多目 的設計探査 (Multi-Objective Design Exploration : MODE)” という呼称で提案している [11]. 本稿で は, MODEの概要を説明するとともに, 空気清浄機 用遠心型ターボファン設計への適用例を示す. 


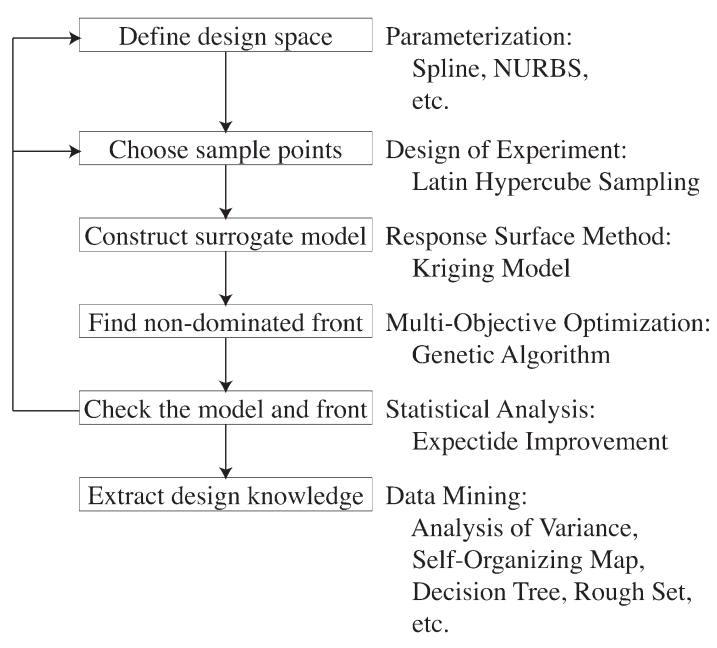

図 2 MODEの手順

\section{2. 多目的設計探查}

MODEのアルゴリズムは, 大きく分けて設計空間 定義, 実験計画法, 応答曲面法, 多目的最適化, 統計 解析, データマイニングからなり, 図 2 のようにまと めることができる，MODEのアルゴリズムの詳細に ついて，順を追って以下で説明する。

\section{1 設計空間定義}

最適化問題を構成する設計变数 - 目的関数 - 制約条 件関数を定式化して, 対象とする設計空間を定義す る. 形状最適化問題の場合, 形状データを構成する点 列座標そのものを設計変数にしてしまうと, 設計変数 の総数が膨大になる。そこで, SplineやNon-Uniform Rational B-Spline (NURBS) などの補間曲線を用いて 形状を表現し, 補間曲線の制御点座標を設計変数とす る.

\section{2 実験計画法}

定義された設計空間全体における目的関数・制約条 件関数の数值データを収集するために, 実験計画法 (Design of Experiment：DOE)を適用する。 MODE では, Latin Hypercube Sampling (LHS) [12]を利用し て設計変数空間上に多数のサンプル点を作成する. 各 サンプル点に対する設計変数值を入力としてCFDな どの数值シミュレーションを行い, その出力として目 的関数・制約条件関数の各值を評価する. LHSは図 3 のように, $n$ 個の設計変数それぞれの定義域を $N$ 等 分割してできた合計 $N^{n}$ 個の部分空間から，直交性条 件を満たすように $N$ 個の部分空間を選択し，各部分 空間内でサンプル点を 1 つずつランダムに作成する

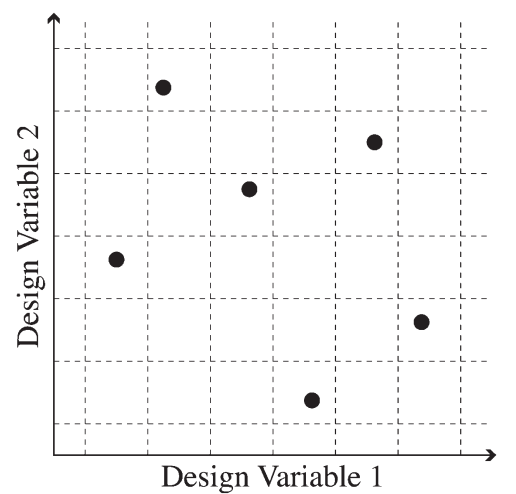

図 3 LHS ( 2 設計変数空間から 6 個のサンプル点を作 成する場合)

(すなわち総サンプル点数は $N$ 個). 直交性条件と は, 選択される $N$ 個の部分空間が各設計変数に対し て重複を持たないことを指す，直交性条件を無視した 単純サンプリングに比べて, LHSは少ないサンプル点 数であっても設計空間全体を網羅できる.

\section{3 応答曲面法}

応答曲面法 (Response Surface Method：RSM[13] とは, 設計空間全体における目的関数・制約条件関数 の大域的分布を単純な代数式として近似することで, 関数評価に要する計算時間を短縮するための手段であ る. 代数式は応答曲面と呼ばれ, 前述のDOEで作成 された数值シミュレーションによる関数“実”值のサン プルデータを補間する形で決定される。この代数式を 用いることで，サンプル点が与えられていない任意の 設計変数值に対する関数值を, 数值シミュレーション を行うことなく，瞬時に“推定”できるようになる。

RSMにはいくつかの手法が提案されているが， MODEではKrigingモデル $[14 ， 15]$ を採用する. Kriging モデルは地中に眠る鉱物資源の埋蔵量推定を起源とし ており，その発展として任意の関数分布をBayes統計 学的に推定する手法である. Krigingモデルは図 4 の ように関数值そのものの分布に加えて，推定される関 数值が含む不確定性(すなわち近似誤差)をそれぞれ代 数式としてモデル化できる. また, 関数推定值・近似 誤差の両モデルを用いて, 近似精度を改善するために サンプル点を追加すべき場所を定量的に特定できる (詳細は次節で述べる). 


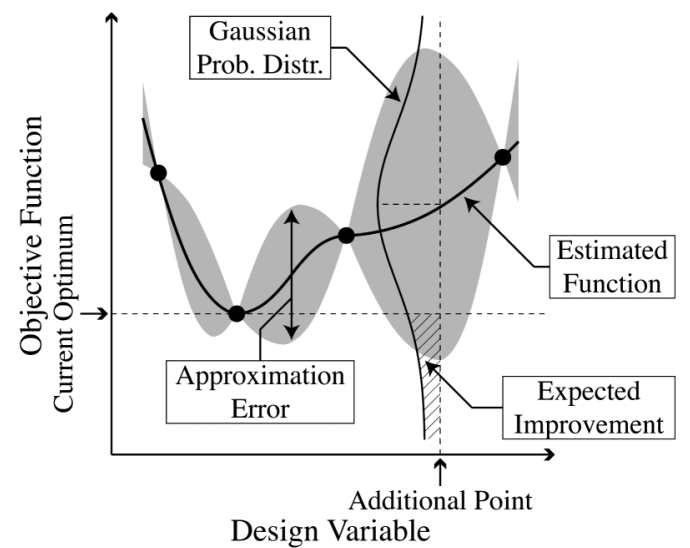

図 4 Krigingモデル (目的関数最小化問題の場合)

\section{4 多目的最適化, 統計解析}

定義された設計問題に対して, 遺伝的アルゴリズム (Genetic Algorithm：GA) [2，3]を用いた多目的最適 化を行い, Pareto最適解集合を探索する。 GAは生物 進化のメカニズムを数值的に再現した最適化手法であ る.ランダムに作られた複数の個体(解)からなる集団 を選択・再生・評価の手順を踏んで進化させていくこ とで, 環境適応度 (目的関数)の高い個体 (最適解)を探 索する。選択過程では, 集団から環境適応度の高い親 個体を選び出す。再生過程では, 親個体が持つ遺伝子 (設計変数)を交叉・突然変異させることで, 子個体を 発生させる。評価過程では, 親個体・子個体の環境適 応度を比較し, 子個体の方が高ければ親個体と入れ換 える(世代交代すなわち解の改善)。今回は, Paretoranking法 [16] と Fitness Sharing [3，16]による適応度 評価, ルーレット選択 [2], Blended Crossover (BLX) [17]による交叉, 非一様突然変異 $[18]$, そしてエリー 卜戦略 $[19 ， 20]$ による世代交代を採用する。

GAは目的関数の勾配評価を必要としないため, 設 計問題に対する適用汎用性に優れる。 また, 多数の設 計候補を同時に改善していくため, 多目的設計問題で 要求されるPareto最適解集合を 1 回の最適化計算で効 率良く得ることができる。ここで, 実際の最適化計算 で得られる解は“真の” Pareto最適解ではなく, あくま でも“近似解”であることに注意されたい。これは，前 節で述べたRSMを使用することからも予想される。

通常の最適化計算では目的関数值そのものの最大化 /最小化を考えるが, MODEでは前節で説明した Krigingモデルから算出される“Expected Improve- ment $(\mathrm{EI})$ 值”の最大化を考える. EI值とは図 4 のよう に, 現在与えられているサンプル点中の最良目的関数 值から見た目的関数の改善量を, 関数推定值 - 近似䛊 差をそれぞれ平均・標準偏差としたGauss型確率分布 のもとで期待值として算出したものである.すなわ ち, 新しいサンプル点を追加して応答曲面を再構築し た時にその点が新たな大域的最適解になりうる確率に 相当する. MODEでは, 各目的関数に関するEI值が 大きくなる場所をGAによって探索し，そこに新たな サンプル点を追加して応答曲面を再構築するという一 連の作業を繰り返すことで, 応答曲面の精度改善と大 域的最適解の発見を同時に目指す。

\section{5 データマイニング}

多目的最適化から得られたPareto最適解集合に対し て, その構造的特徴を調べるためにデータマイニング を適用する。これまでに様々なデータマイニング手法 が提案されているが, 得られる情報形体 (数值, 画 像, 文章など) はデータマイニング手法によって大き く異なる。 また, 情報が示唆する内容自体も各手法で 異なる可能性が考えられる。そこで今回は, データマ イニング手法を 1 つに限定せず, 以下の複数の手法を 併用しながら設計空間構造を明らかにしていくアプ ローチを提案する。

\subsection{1 自己組織化マップ}

自己組織化マップ(Self-Organizing Map：SOM) [21]は, 教師なし学習のアルゴリズムを用いる 2 層 フィードフォーワード型のニューラルネットモデル (図 5 ) である. 入力層の各ニューロンには分析対象の 多次元ベクトルデータ (個々のPareto最適解の目的関 数值データ)を与える. 出力層のニューロン群は 2 次 元平面上に矩形あるいは六角形の格子配列をとり, 各 ニューロンにはあらかじめ入力ベクトルと同次元の重

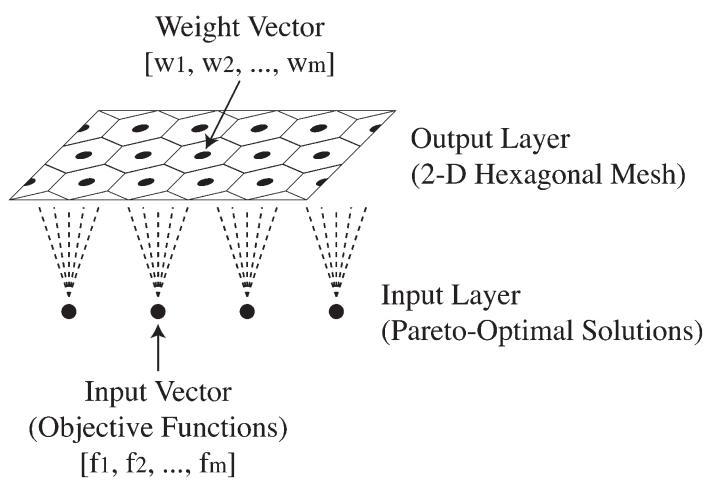

図 5 SOM 
みベクトルをランダムに与えておく，各入力ベクトル に対して, 出力層ではそれに最も近い重みべクトルを 持つニューロン（最良ユニット）を探索し，最良ユニッ トとその近接ニューロンの重みベクトルを調整して入 カベクトルに近付けていく，この調整作業を繰り返す ことで, 類似した入力ベクトルは出力層でも近接した ニューロンに射影されるようになる。こうしてできた 2 次元平面上での入力ベクトルの配置をSOMの結果 として図示する。

SOMの結果は, 元の多次元データに含まれていた 特徴を保持した状態で, 多次元データを 2 次元に折り 畳んで表現したものである。すなわち，SOMを用い ると多次元データの可視化ができる。ただし，SOM は我々が直感的に理解している地図とは異なり，方向 や距離の意味を持たないことに注意されたい，今回 は，市販ソフトゥェアViscovery SOMine[22]を用い てSOMデータマイニングを実行する。

\subsection{2 決定木}

決定木 [23]は, 統計学に打ける分散分析 (Analysis of Variance：ANOVA) [15，24]を応用したクラスタ リング手法の1つである。これを分析対象のPareto最 適解集合に適用すると，以下のようになる。ある $1 つ$ の設計変数のある閾值をもってPareto最適解集合を 2 つのグループに分割し，それぞれのグループに属する Pareto最適解の目的関数の平均值を計算する。兵し て, 各グループの平均值の差が最大となるような設計 変数および閾值を探索する。この一連の作業を分割さ れたグループに対しても同様に繰り返し施すことで, 元のPareto最適解集合を複数のグループヘとクラスタ リングすることができる。なお，決定木を用いたデー タマイニングは各目的関数について個別に行われる.

これらのグループ分割過程は, 図 6 のように個々の ブロックが分割グループに対応した樹形図としてまと められる。そしてルートノードから任意のリーフノー ドへの経路を辿ることで, 統計的に有意な $1 つ の$ 設計

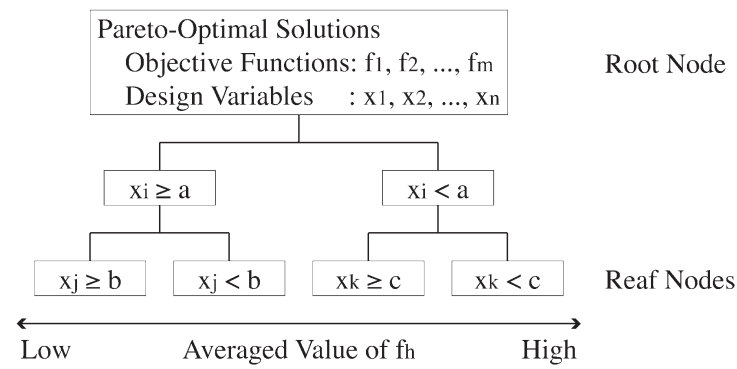

図 6 決定木 ルールが“if-then形式”で得られる。この性質から，設 計变数に対する目的関数の応答が線形的で感度が高い 設計変数ほど上位のノードに位置するため, 各設計変 数の重要度を明らかにできるのが特徴である。

\subsection{3 ラフ集合}

ラフ集合 $[25]$ は集合演算を応用したルール抽出法で ある。ラフ集合で扱うデータの属性值は離散值に限ら れるため, 分析対象のPareto最適解集合の目的関数 值・設計変数值それぞれを離散化する。今回は各属性 值を 5 水準 ( 1 : 小, 2 : 中小, 3 : 中, 4 : 中大, 5 ：大)に分割し, 各水準に同数のPareto最適解が含 まれるように離散化する。このように離散化を施され たPareto最適解集合は, 各設計変数を所定の水準值に 設定していくと各目的関数が特定の水準値になるとい うif-then形式の設計ルールの集合体とみなすことが できる。このままではすべての設計変数について条件 式を伴う複雑なif-thenルールとなるが, 設計変数の 中には目的関数の水準決定に寄与しないようなものも ある。そこで，これらを省略して簡略なルールを集合 演算によって求める(縮約という). 縮約には複数のパ ターンがあるのが通常である。

決定木が 1 つの設計ルールを求めるのと異なり， ラ フ集合では縮約のパターンの数だけ多数の設計ルール が得られるという利点がある。しかし, 得られたルー ルの重要性について順位づけが難しいという久点があ る。今回は, フリーソフトウェアROSETTA[26]を利 用してラフ集合データマイニングを実行する.

\section{3 . ターボファン設計への適用}

前節で説明したMODEを空気清浄機用遠心型ター ボファン設計に適用して, 設計空間の構造的特徴を調 査したのち, 性能改善のための有益な設計知識を抽出 する.

\section{1 設計問題定義}

高効率・低騒音を同時に実現できる 9 枚羽根ファン (図 7 )の多目的最適設計を取り上げる。設計対象の 3 次元羽根形状は, 子午面形状 (図 $8(\mathrm{a})$ ) ・キャンバー 角度分布 (図 8 (b), 周方向となす角度として定義) • 厚み分布(図8 (c)) の重ね合わせとして表現する。こ れらの形状打よび分布の制御パラメータ(計17個)が設 計変数である。

目的関数は, 流量 $6.0 \mathrm{~m}^{3} / \mathrm{min}$, 回転数 $1580 \mathrm{~min}^{-1}$ の 作動条件下での, 異なる 3 種類の定義の空力効率の最 大化と乱流騒音レベルの最小化の計 4 つである. 


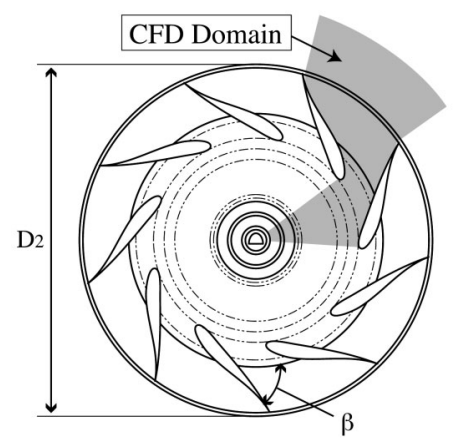

(a) 上面図

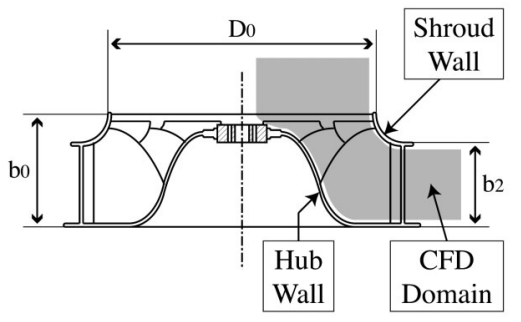

(b) 側面図

図 7 空気清浄機用遠心型ターボファン

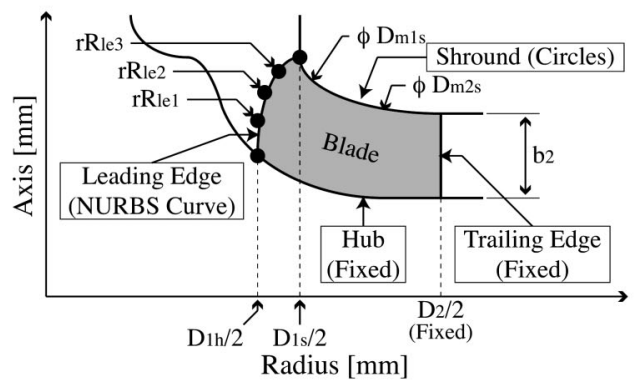

(a) 子午面形状

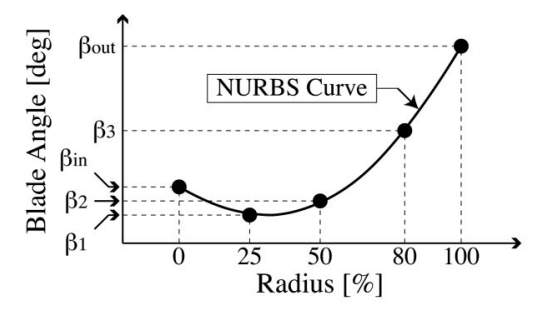

(b) キャンバー角度分布

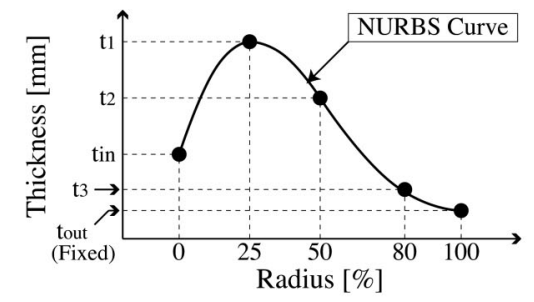

(c) 厚み分布

図 8 羽根形状定義
- 全圧効率 $\eta_{t}$ の最大化

$$
\eta_{t}=\frac{\left(p_{t 2}-p_{t 1}\right) Q}{W_{a x}}
$$

- 静圧効率 $\eta_{s}$ の最大化

$$
\eta_{s}=\frac{\left(p_{s 2}-p_{s 1}\right) Q}{W_{a x}}
$$

- スクロール効果を加味した静圧効率 $\eta_{\text {all }}$ の最大化

$$
\eta_{\text {all }}=\eta_{s}+\frac{\eta_{\text {scroll }}\left[\frac{1}{2} \rho\left(C_{2}^{2}-C_{e}^{2}\right)\right] Q}{W_{a x}}
$$

$p_{t}$ は全圧, $p_{s}$ は静圧, $Q$ は流量, $W_{a x}$ は軸入力パ ワー, $\rho$ は密度, $C$ は絶対速度, $\eta_{\text {scroll }}$ はスクロール効 率である。下付き添字の $1,2, e$ はそれぞれ, 羽根入 口, 羽根出口, スクロール出口を表す。

・乱流騒音レベル $L_{s}$ の最小化

$$
\begin{aligned}
& L_{s}=L-10 \log _{10}\left[\left(\frac{\Delta P}{g}\right)^{2} Q\right] \quad[\mathrm{dB}] \\
& \text { ここで } \\
& L=10 \log _{10}\left[\alpha\left(W_{1}{ }^{6}+W_{2}^{6}\right) D_{2}^{2} Z\right]+\beta \\
& \Delta P=\frac{W_{a x} \eta_{s}}{Q}+\eta_{\text {scroll }}\left[\frac{1}{2}\left(C_{2}{ }^{2}-C_{e}{ }^{2}\right)\right]
\end{aligned}
$$

$g$ は重力加速度, $W$ は相対速度である。

また，軸入力が規定範囲に収まるよう，以下の制約条 件を考慮する。

- 軸入力 $W_{a x}$ に関する制約条件

$$
37.0 \leq W_{a x} \leq 41.0
$$

図 7 中の灰色領域で示される 1 ピッチ分の領域に対し て周期境界条件を仮定した CFD解析を行い, 上記の 目的関数・制約条件関数を評価する.

\section{2 計算条件}

LHSにより設計空間全体に作成された 145 個の初期 サンプル点を用いて，4 つの目的関数 $\left(\eta_{t}, \eta_{s}, \eta_{\text {all }}\right.$, $\left.L_{s}\right)$ および 1 つ制約条件関数 $\left(W_{a x}\right)$ それぞれに対し てKrigingモデルによる応答曲面を構築した。 GAによ る多目的最適化では，500個体の集団を200世代に 渡って更新した。また，GAの再生過程における突然 変異の発生確率を $10 \%$ とした. 多目的最適化から得ら 
れたPareto最適解集合(実際には“近似解”)に対して は，SOM，決定木，ラフ集合のそれぞれを適用して データマイニングを行った(その他, 詳細は文献 $[27$, 28]を参照されたい).

なお, 今回得られたPareto最適解集合の各目的関数 值・制約条件関数值について, 応答曲面による推定値 と実際のCFD解析による実值を比較したところ, 解 集合平均で最大 $5.2 \%$ の誤差が含まれることが確認さ れた。この程度の誤差は現行品からの性能改善量に比 べて十分に小さいため, 最適化計算での解の改善方向 の探索には差し支えない。また，得られたPareto最適 解集合の収束性についても, 最適化計算での世代に対 する目的関数の解集合平均值の履歴から確認されてい る。

\section{3 計算結果}

\subsubsection{SOMデータマイニング}

Pareto最適解集合が持つ 4 次元の目的関数值データ を 2 次元のSOMに射影し, 各目的関数值で色付けし たものを図 9 (a) - 9 (d) に示す。な打, 空力効率の值 にはマイナスを掛けて, 值の小さい(色の黒い)領域ほ ど目的関数值の良い解に対応するようにすべての SOMを統一してある。

全圧効率 $\eta_{t}$ (図 $9(\mathrm{a})$ ) とスクロール効果を加味した 静圧効率 $\eta_{\text {all }}$ (図 9 (c) ) を比較すると，元れぞれの SOMのカラーパターンが似ている。つまり，これら の目的関数は相反せず，一方を改善するともう一方も 同時に改善する関係にあることが分かる。一方，静圧 効率 $\eta_{s}$ (図 9 (b))のSOMは反転したカラーパターンに なっており， $\eta_{t}$ および $\eta_{\text {all }}$ と相反する関係にあること が分かる。 $\eta_{s}$ が大きくなると，逆圧力勾配の影響で ファン内部の流れはより拡散的になる。その結果, 出 口全圧が小さくなり， $\eta_{t}$ および $\eta_{\text {all }}$ が小さくなる。言 い換えると， 3 種類の空力効率間のトレードオフはす べて, $\eta_{s}$ の増減傾向だけで決まる。

$\eta_{s}($ 図 $9(\mathrm{~b}))$ と乱流騒音レベル $L_{s}$ (図 $9(\mathrm{~d})$ ) を比較 すると, これらの目的関数は強いトレードオフの関係 にあることが分かる，前段落の議論を踏まえると，本 設計問題は 4 つの目的関数で定義されているが, 実質 的には $\eta_{s}$ と $L_{s}$ の 2 つの目的関数のみを考慮すればす ベてのトレードオフを議論できると言える。

静圧効率 $\eta_{s}$. 乱流騒音レベル $L_{s}$ をそれぞれ横・縦 軸とした平面上に, Pareto最適解集合を投影したもの を図10に示す。また，トレードオフ線上にある解 $\mathrm{A}-\mathrm{E}$ それぞれに対応する羽根断面形状も併せて示す．静圧 効率重視の設計をすると, 羽根が薄く, 反り線が滑ら かになる傾向にある。逆に低騒音重視の設計をする

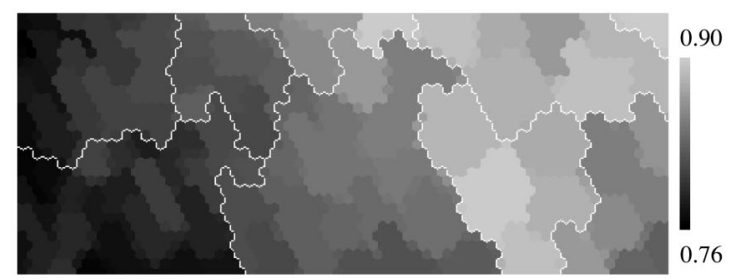

(a) 全圧効率 $\left(-\eta_{t}\right)$

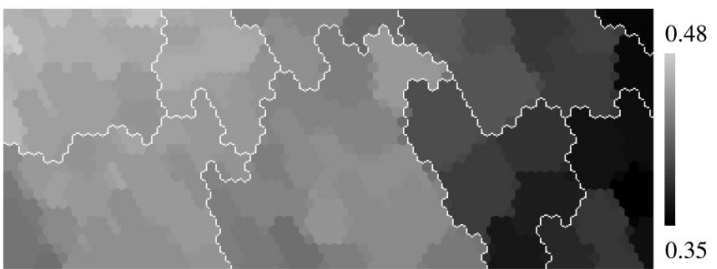

(b) 静圧効率 $\left(-\eta_{s}\right)$

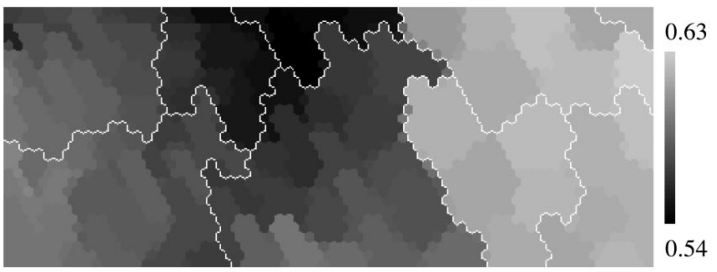

（c）スクロール効果を加味した静圧効率 $\left(-\eta_{\text {all }}\right)$

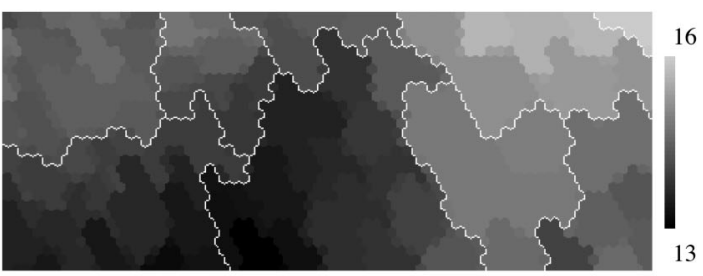

(d) 乱流騒音レベル $\left(L_{s}\right)$

図9SOMデータマイニングの結果

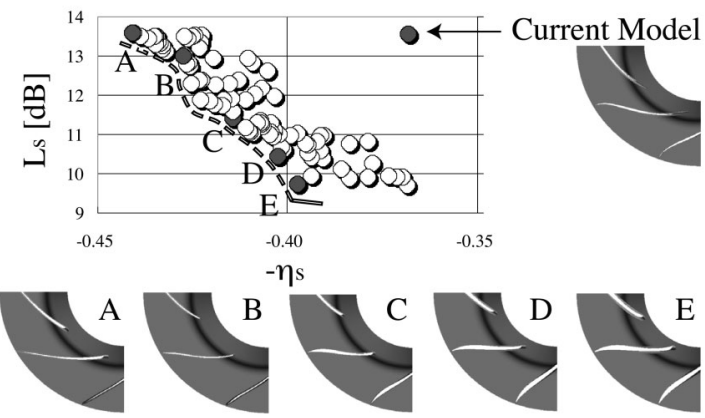

図10 静圧効率 $\eta_{s}$ と乱流騒音レベル $L_{s}$ のトレードオフ 関係 
と, 羽根入口径は小さめに，そり線は変曲点を持つよ うになり, 羽根厚みの制御が必要となる様子が分か る. 騒音エネルギーが翼間の相対流速の 6 乗に比例す るという予測モデルを用いているため, 羽根入口径が 騒音に強く関係するパラメータとなった。

SOMは, 複数の目的関数間に存在するトレードオ フ構造を 2 次元画像上に射影できるため, 多目的最適 化問題の議論を単純化するのに役に立つ。しかし，画 像の見方は設計者の主観に依るところも多く，そこか ら得られる設計ルールも設計者次第で大きく変わる可 能性もある。

\subsection{2 決定木データマイニング}

静圧効率 $\eta_{s}$ と騒音レベル $L_{s}$ について, 決定木を適 用した結果をそれぞれ図11(a)，11(b)に示す。

ファンの静圧効率を重視する場合の設計ルールは, 図11(a)の樹形図中の灰色で示したノードを右下へと 辿ることで得られる。すなわち，シュラウド側の翼入 口径 $D_{1 s}\left(D_{2}\right.$ は固定)を小さめとし，中間径における 羽根角度 $\beta_{3}$ を小さめに抑えるというルールである。 本ファンでは, シュラウド面の曲率がきついために, ファン入口部のシュラウド面において剥離泡が存在す るが，羽根前縁径を小さくして空力仕事を与えること で, この領域をできる限り抑えながら, 翼負荷分布を 制御するといったトレードオフ制御に関する知見が得 られる。なお，樹形図左側に表れる $t_{2}$ は中間径におけ る翼厚みである。

一方，低騒音性を重視する場合の設計ルールは， 図11(b)の樹形図中の灰色で示したノードを左下へと 辿ることで得られ，やはりシュラウド側の翼入口径 $D_{1 s}$ を小さく, 同時に八ブ側の翼入口径 $D_{1 h}$ も小さく

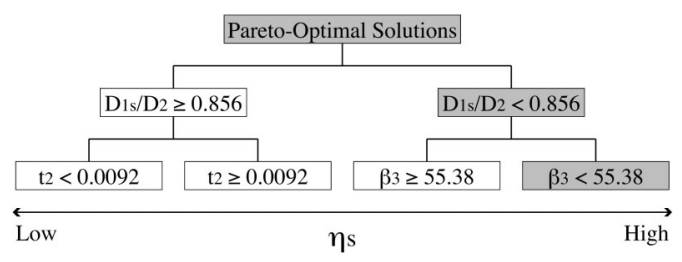

(a) 静圧効率 $\left(\eta_{s}\right)$

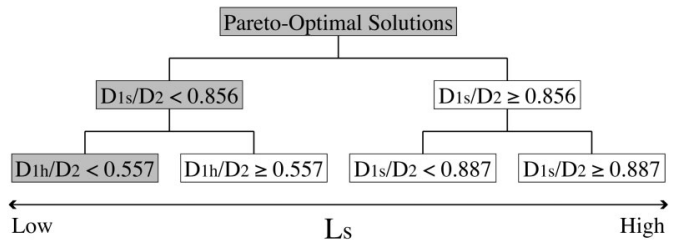

(b) 乱流騒音レベル $\left(L_{s}\right)$
することが有効であることが示されている。これは羽 根入口径を小さくし，ファン入口相対流速を低減させ るため, 乱流騒音レベルが小さくなると解釈できる. このように，得られるルールは1つであるが，設定す べき設計変数の水準值が優先順位とともに定めること ができ, わかりやすいルールとして抽出できるのが決 定木の特徴である。

\subsection{3 ラフ集合データマイニング}

ラフ集合によって静圧効率 $\eta_{s}$ と騒音レベル $L_{s}$ の間 のトレードオフを制御するためのルールを求めた結果 を，図12(a)，12(b)に示す。ここでは, 図 9 (a)-9 (d) に示したSOM上で, $-\eta_{s}, L_{s}$ それぞれの值が最小と なる解 (“極限解” と呼ぶ) が存在するクラスターに帰属 するためのルールを求めた。 ラフ集合で得られた設計 ルールの数が多かったため, ルールに共通して現れる 設計変数とその水準值に着目し，ルールの解釈を行う こととした。罒12(a)，12(b)では，得られたすべて のルール中に現れる各設計変数の水準值の平均と標準 偏差(水準の確度に相当)を示している。 なお，罒中の 破線枠で囲んだ設計変数は, ルールとして重複して抽 出された回数が上位のものを示して打り, 今回重要と 考えた設計変数である。

四12(a)からは, 羽根出口近傍の羽根角度 $\beta_{3}$ を低水 準 (小さな值)に抑え, 羽根出口角 $\beta_{\text {out }}$ を中程度にする

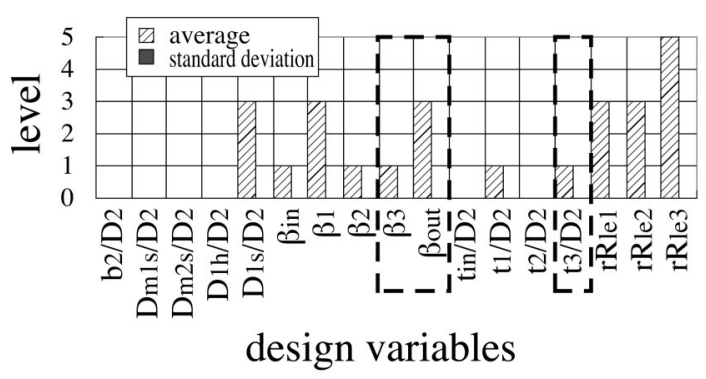

(a) 静压効率 $\left(\eta_{s}\right)$

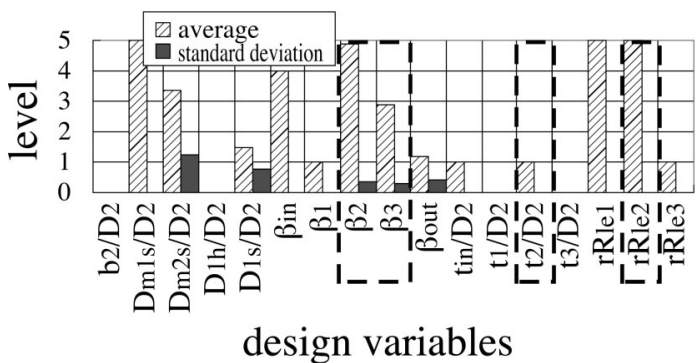

(b) 乱流騒音レベル $\left(L_{s}\right)$

図12 ラフ集合データマイニングの結果

図11＼cjkstart決定木データマイニングの結果 
こと, 羽根出口近傍の翼厚み $t_{3}$ を小さく設定すること が効率重視の設計に必要であることが示されている.

トレードオフ制御に関して翼負荷分布がポイントと なっている点は決定木と同様な結果であるが，決定木 で得られた設計変数 $D_{1 s}$ はここでは抽出されていな い. 図12(b)でも, 羽根角度 $\beta_{2}$ や $\beta_{3}$, 羽根厚み $t_{2}$ な どについて決定木とは別の切り口の低騒音化指針が得 られている。

これらのラフ集合の結果は, 決定木で得られるルー ルよりも多様性があるものの, 主要なルールが異なっ ている。.ラフ集合では, 目的関数の属性決定に影響を 与えない設計変数は縮約されるため, 目的関数に対す る感度が非常に大きく常に設計変数水準が一定となっ てしまう場合か，もしくは非常に感度が小さくて水準 変化が結果に影響を与えないような場合に, 縮約され ルールとして抽出されない可能性がある. 今回の $D_{1 s}$ のような変数は, 前者のような原因で抽出されなかっ たのではないかと推定される。

\section{4. 結言}

本稿では, ある特定の性能に対する単一の最適設計 候補を提示することを目的とした従来の最適化に代わ り, 複数の設計目標を考慮した多目的最適化問題を解 いて多様な最適設計候補を求め, 沉用性に富んだ有益 な設計知識を提示するという新しい設計プロセスとし て，“多目的設計探查”という概念を提案した。多目的 設計探査では, 多目的最適化計算から得られる多次元 の数值データ (Pareto最適解集合)に対してデータマイ ニングを適用して，設計トレードオフといった多目的 設計空間の構造的特徵を俯瞰的に可視化する。データ マイニング結果をもとに, 設計者は容易に設計知識を 抽出できるようになる。

また本稿では, 多目的設計探査を空気清浄機用遠心 型ターボファン設計に適用した例を示した。ここで は，自己組織化マップ・決定木・ラフ集合の計 3 種類 の手法を用いてデータマイニングを行った．抽出され る設計知識がデータマイニング手法によって異なるこ とから, 多様な設計知識を発見するためには様々な データマイニング手法を併用することが理想的であ る。

非常に深い知識と製品固有の経験を積んだ設計者で あれば, どのパラメータが性能に効くかは認識でき る。しかし, 複数のトレードオフ関係の中で相互に関 連付けられた形で知識が整理されているか(全体俯瞰 した知識の中で位置付けられているか)，あるいは効 くことは分かっていてもそれを定量的に決定できるか は分からない。 また, 経験が活用できない寸法や構造
に設計変更がなされる場合や, 専門家以外の人が設計 に取り組む場合も考えられる。多目的設計探査は，こ ういった設計者にとって有効な設計ツールとなること が期待される。

本稿の例は, 最適化が単にブラックボックスとして 設計問題の答えをもたらすものではなく, 設計問題に ついての知識をもたらす可能性を持つことを示してい る。計算科学に打けるシミュレーションは, 最適化を 通じてデータマイニングと出会うことで, 自然現象の 再現から知識発見に展開しているといえよう。

\section{参 考 文 献}

[1] G. N. Vanderplaats. Numerical Optimization Techniques for Engineering Design: With Applications. McGraw-Hill, Inc., New York, NY, 1984.

[2] D. E. Goldberg. Genetic Algorithms in Search, Optimization and Machine Learning. Addison-Wesley Publishing Company, Inc., Reading, MA, 1989.

[ 3 ] K. Deb. Multi-Objective Optimization using Evolutionary Algorithms. JohnWiley \& Sons, Ltd., Chichester, 2001.

[ 4 ] J. Kennedy and R. Eberthart. Particle swarm optimization. In Proceedings of the 4th IEEE International Conference on Neural Networks, pp.1942-1948. IEEE Service Center, Piscataway, NJ, 1995.

[ 5 ] I. Das and J. E. Dennis. Normal-boundary intersection : A new method for generating the pareto surface in nonlinear multicriteria optimization problems. SIAM Journal on Optimization, Vol.8, No.3, pp.631657, 1998.

[6] H. Nakayama. Aspiration level approach to interactive multi-objective programming and its applications. In P. M. Paldalos, Y. Siskos, and C. Zopounidis, editors, Advances in Multicriteria Analysis, pp.1477-174. Kluwer Academic Publishers, Dordrecht, 1995.

[ 7 ] E. J. Hughes. Evolutionary many-objective optimization : Many once or one many? In Proceedings of the 2005 IEEE Congress on Evolutionary Computation, pp.222-227. IEEE Press, Piscataway, NJ, 2005.

[ 8 ] H. Ishibuchi, N. Tsukamoto, and Y. Nojima. Evolutionary many-objective optimization : A short review. In Proceedings of the 2008 IEEE Congress on Evolutionary Computation, pp.2419-2426. IEEE Press, Piscataway, NJ, 2008.

[ 9 ] S. Obayashi, K. Deb, C. Poloni, T. Hiroyasu, and T. Murata, editors. Evolutionary Multi-Criterion Optimization, 4th International Conference. Lecture Notes in Computer Science 4403. Springer-Verlag, Berlin Heidelberg, 2007.

[10] M. Kantardzic. Data Mining : Concepts, Models, Methods and Algorithms. IEEE Press/John Wiley \& Sons, Inc., 2003.

[11] S. Obayashi, S. Jeong, and K. Chiba. Multi-objective design exploration for aerodynamic configurations. AIAA Paper2005- 4666 (invited paper), 2005.

[12] M. D. McKay, R. J. Beckman, and W. J. Conover. A 
comparison of three methods for selecting values of input variables in the analysis of output from a computer code. Technometrics, Vol.21, No.2, pp.239-245, 1979.

[13] R. H. Myers and D. C. Montgomery. Response Surface Methodology : Process and Product Optimization Using Designed Experiments. John Wiley \& Sons, Inc., New York, NY, 1995.

[14] J. Sacks, W. J. Welch, T. J. Mitchell, and H. P. Wynn. Design and analysis of computer experiments. Statistical Science, Vol.4, No.4, pp.409-435, 1989.

[15] D. R. Jones, M. Schonlau, and W. J. Welch. Efficient global optimization of expensive black-box function. Journal of Global Optimization, Vol. 13, pp.455-492, 1998.

[16] C. M. Fonseca and P. J. Fleming. Genetic algorithms for multiobjective optimization : Formulation, discussion and generalization. In Proceedings of the 5th International Conference on Genetic Algorithms, pp.416-423. Morgan Kaufmann Publishers, Inc., San Mateo, CA, 1993.

[17] L. J. Eshelman and J. D. Schaffer. Real-coded genetic algorithms and interval schemata. In Foundations of Genetic Algorithms 2, pp.187-202. Morgan Kaufmann Publishers, Inc., San Mateo, CA, 1993.

[18] M. Gen and R. Cheng. Genetic Algorithms and Engineering Optimization. John Wiley \& Sons, Inc., New York, NY, 2000.

[19] L. J. Eshelman. The CHC adaptive search algorithm : How to have safe when engaging in nontraditional genetic recombination. In Foundations of Genetic Algorithms, pp.265-283. Morgan Kaufmann Publishers, Inc., San Mateo, CA, 1991.

[20] S. Tsutsui and Y. Fujimoto. Forking genetic algorithms with blocking and shrinking modes (fGA). In Pro- ceedings of the 5th International Conference on $\mathrm{Ge}$ netic Algorithms, pp.206-213. Morgan Kaufmann Publishers, Inc., San Mateo, CA, 1993.

[21] T. Kohonen. Self-Organizing Maps. SpringerVerlag, Berlin Heiderberg, 1995.

[22] Eudaptics Software GmbH. http://www.eudaptics.com/somine/.

[23］元田浩, 津本周作, 山口高平, 沼尾正行. データマイ ニングの基礎。オーム社，東京， 2006.

[24] B. Efron and C. Stein. The jackknife estimate of variance. The Annals of Statistics, Vol. 9, No. 3, pp.586596, 1981.

[25] K. J. Cios, W. Pedrycz, and R. W. Swiniarski. Data Mining Methods for Knowledge Discovery. Kluwer Academic Publishers, Norwell, MA, 1998.

[26] ROSETTA. http://rosetta.lcb.uu.se/general/.

[27] K. Sugimura, Y. Iwase, K. Shimoyama, S. Jeong, and S. Obayashi. Multi - objective design optimization of an air cleaner fan using kriging models. In Proceedings of International Workshop on Multidisciplinary Design Exploration in Okinawa 2006, pp.105-112, 2006.

[28］杉村和之, 大林茂, 鄭信圭. 遠心ファン最適設計デー タベースに対する設計知識マイニング手法の適用. 日 本機械学会 2007 年度年次大会講演論文集, Vol.6, pp.165-166, 2007.

（2008年10月16日＼cjkstart受付）

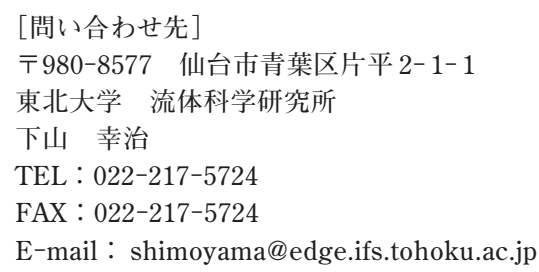




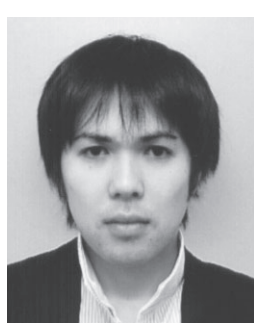

\section{者山朕治 [非会員]}

青森県出身. 2001 年東京大学工学 部機械工学科卒業. 2006 年同大学院 工学系研究科航空宇宙工学専攻博士課 程修了, 博士 (工学)。同年より東北 大学流体科学研究所教育研究支援者, 現在に至る.進化的アルゴリズムを用 いたロバスト設計・信頼性設計を中心 に, 流体力学・構造力学の数值シミュ レーションに関する研究に従事. 日本 航空宇宙学会, 日本機械学会, AIAA各 会員.

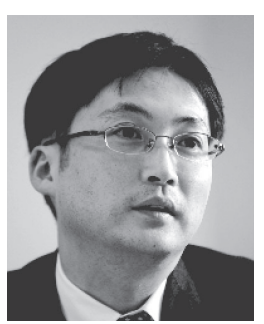

\section{鄭信圭 [非会員]}

大韓民国釜山広域市出身。1995 年 慶熙大学校工学部機械工学科卒業. 1999 年東北大学大学院工学研究科航 空宇宙工学専攻博士後期課程修了, 工 学博士. 2001 年航空宇宙技術研究所 (現宇宙航空研究開発機構) 研究員. 2004年東北大学流体科学研究所助手. 2007 年より同研究所准教授, 現在に 至る.実用設計に向けた最適設計に関 する研究に従事. 韓国航空宇宙学会, 日本航空宇宙学会, 日本機械学会, AIAA 各会員.

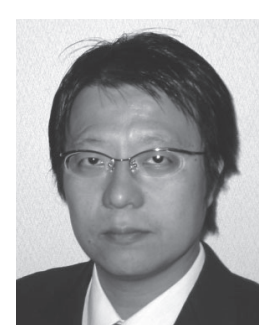

すぎむら かず中き
杉村 和之 [非会員]

愛知県出身. 1994 年東京大学工学 部航空宇宙工学科卒業. 1996 年同大 学院工学系研究科航空宇宙工学専攻修 士課程修了。同年 (株) 日立製作所入 社. 同社機械研究所にて各種ターボ機 械や新幹線等の流体解析, 製品開発に 従事。2001 年英国ケンブリッジ大学 訪問研究員. 以後, ターボ機械を主対 象とした最適設計技術, 設計知識マイ ニング技術の開発と製品適用に従事, 現在に至る。2006 年より東北大学大 学院情報科学研究科博士後期課程にも 在籍. 日本機械学会, ターボ機械協 会, IEEE 各会員.

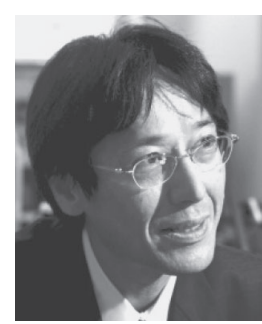

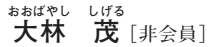

横浜市出身. 1982年筑波大学第 1 学 群自然学類卒業. 1987 年東京大学大 学院工学系研究科航空学専攻博士課程 修了, 工学博士. 同年 NASA Ames Research Center NRC Research Associate. 1989 年同研究所 MCAT Institute Senior Research Scientist. 1994 年東北大学工学部助教授. 2000 年同大学流体科学研究所に配置換え. 2003 年より同研究所教授, 現在に至 る. 数值流体力学, 最適化, データマ イニング等の研究に従事. 1993 年 NASA Ames Honor Award, 2002 年 NASA Software Release Award, 2002 年日本機械学会計算力学部門業績賞等 を受賞. 文部科学省航空科学技術委員 会委員. 日本航空宇宙学会, 日本機械 学会, 日本流体力学会, 日本計算工学 会, IEEE, AIAA各会員. 